\title{
Genetic Analysis of Yield and Yield Contributing Quantitative Traits in Bread Wheat Under Sodium Chloride Salinity
}

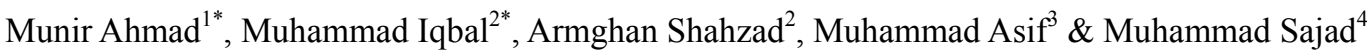 \\ ${ }^{1}$ Department of Plant Breeding and Genetics, PMAS-Arid Agriculture University Rawalpindi, Pakistan \\ ${ }^{2}$ Plant Biotechnology Program (NIGAB) National Agriculture Research Center Park Road Islamabad, Pakistan \\ ${ }^{3}$ Department of Agricultural, Food and Nutritional Science, University of Alberta, Edmonton, AB, Canada \\ ${ }^{4}$ Department of Plant Breeding and Genetics, University College of Agriculture and Environmental Sciences, The \\ Islamia University of Bahawalpur, Punjab, Pakistan \\ *First two authors contributed equally. \\ Correspondence: Armghan Shahzad, Plant Biotechnology Program (NIGAB), National Agriculture Research \\ Center Park Road, Islamabad 45500, Pakistan. E-mail: armghan_shehzad@yahoo.com
}

Received: January 25, 2013 Accepted: March 21, 2013 Online Published: May 15, 2013

doi:10.5539/jas.v5n6p156 URL: http://dx.doi.org/10.5539/jas.v5n6p156

\begin{abstract}
The genetic basis of salt tolerance was investigated in six bread wheat cultivars (Local white, Pavon, Pasban 90, Frontana, Tobari 66 and Chakwal 97) differing in salinity tolerance, and their $\mathrm{F}_{1}$ crosses made in a half diallel mating design. The $\mathrm{F}_{1} \mathrm{~S}$ and parents were germinated in pots, and were subjected to $200 \mathrm{mM} \mathrm{NaCl}$ salt stress after one month. Most of the crosses had high heterosis for yield suggesting that breeding for high yield under salt stress is possible. Narrow sense $\left(\mathrm{h}^{2}{ }_{\mathrm{N}}\right)$ heritability estimates ranged from 0 to $51 \%$, whereas broad sense $\left(\mathrm{h}^{2}{ }_{\mathrm{B}}\right)$ heritability estimates ranged from 25 to $84 \%$ for the studied traits. Additive genetic effects were significant for days to heading, days to maturity, plant height and fertile tillers plant ${ }^{-1}$, suggesting that early selection could be useful to bring desirable changes in these characters under $\mathrm{NaCl}$ stress. Dominance effects were significant for yield and yield contributing traits, indicating that selection for yield under $\mathrm{NaCl}$ stress would be effective in later generations.
\end{abstract}

Keywords: diallel analysis, quantitative traits, bread wheat, salinity tolerance

Abbreviations: GCA, general combining ability SCA, specific combining ability AD, Additive-Dominance AUP, Adjusted Unbiased Prediction MPH, mid parent heterosis BPH, better parent heterosis

\section{Introduction}

Salinity is the oldest and severe abiotic stress which limits crop production in arid and semi arid areas of the world. Over 800 million hectares of land are salt affected throughout the world (Munns, 2005). In Pakistan, about six million hectares are salt affected (Chatrath et al., 2007). One of the possible ways to bring saline marginal soils under crop cultivation is to develop salt tolerant crop cultivars instead of pricey engineering approaches (Qureshi et al., 1990). Furthermore heterosis breeding approaches offers the way to surmount the yield barriers (Kumar et al., 2011).

Salt tolerant crop varieties can be developed by conventional methods if genetic variation for salinity tolerance exists in the available germplasm. Genetic variation with high heritability is desirable for direct phenotypic selection. Only a few cycles of selection could result in significant improvement in salinity tolerance. Diallel cross designs are frequently used in plant breeding research to obtain information on genetic effects for a fixed set of parental lines or estimates of general combining ability (GCA) and specific combining ability (SCA), variance components and heritability for a population from randomly chosen parental lines. Diallel analysis is a reliable mechanism to understand the type of gene action controlling complex genetic traits of economic importance (Inamullah et al., 2006). Knowledge of broad sense heritability, narrow sense heritability, GCA and SCA is useful in the choice of parental genotypes. Combining ability studies assist in the identification of parents with greater GCA values and parental combinations with greater SCA values. 
High heritability values of traits which confer salinity tolerance in spring wheat indicated that a major progress in salinity tolerance may be possible through selection by the imposition of high selection pressure (Ashraf, 1994). Selection of plants exhibiting better combination of desirable traits is easy if variation is controlled by additive gene effects. Stuber (1994) reported that assessment of additive and non-additive gene action could be helpful in determining the possibility of commercial utilization of heterosis and isolation of pure lines among the progenies of the good hybrids. S. Singh and M. Singh (2000) reported that salinity sensitive parent response was partially dominant, whereas the tolerant parent showed partial dominance for yield potential. Salinity tolerance and yield potential appeared to be controlled by different gene complexes.

The present study was initiated to estimate the morphological traits related to salt tolerance and to determine the type of gene action controlling salt tolerance in wheat under $200 \mathrm{mM} \mathrm{NaCl}$ stress.

\section{Materials and Methods}

\subsection{Plant Material and Growth Conditions}

Seeds of the six bread wheat varieties (Local white, Pavon, Pasban 90, Frontana, Tobari 66 and Chakwal 97) differing in salinity tolerance were taken from the gene bank of Plant Genetic Resources Program, NARC Islamabad. These cultivars were crossed in a one-way diallel mating design to obtain a total of $15[(6(6-1) / 2]$ cross combinations. F1 seeds along with their parents were sown in pots in a randomized complete block design (RCBD) having three replications. After one month of germination, $200 \mathrm{mM} \mathrm{NaCl}$ salt stress was given to all $\mathrm{F}_{1}$ and parents. Two plants were maintained in each pot. One pot represented one replication. Data were recorded for plant height, No. of tillers plant-1, days to heading, days to maturity, spike length, number of spikelets spike ${ }^{-1}$, number of grains spike $^{-1}, 100$ gain weight and grain yield plant ${ }^{-1}$.

\subsection{Data Analysis}

The Mixed Procedure in SAS (SAS Institute, 2003) was used to analyze the data. Likelihood ratios were computed as described by Iqbal et al. (2007). Diallel analysis was carried out using the average of parental values and $F_{1}$ crosses values by utilizing an Additive-Dominance (AD) model following Zhu (2003). Components of genetic variance were calculated following Rao (1971). Genetic effects were estimated using the Adjusted Unbiased Prediction (AUP) method of Zhu and Weir (1996). Estimates of narrow-sense heritability were obtained by the formula $h^{2}{ }_{N}=V_{A} / V_{P}$, and those of broad-sense heritability by $h^{2}{ }_{B}=\left(V_{A}+V_{D}\right) / V_{P}$. The significance of components of variance was tested by means of one-tailed t-test, and those of genetic effects by two-tailed t-tests. Genetic analyses were done using the software "QGA Station 1.0" developed by Chen and Zhu (2003). Heterosis was determined for each cross as the percentage deviation of $F_{1}$ means from mid parent means (MP) and better parent (BP) following the formulae given by Dreisigacker et al. (2005).

$$
\begin{aligned}
\mathrm{MPH}(\%) & =\left(\mathrm{F}_{1}-\mathrm{MP}\right) / \mathrm{MP} \times 100 \\
\mathrm{BPH}(\%) & =\left(\mathrm{F}_{1}-\mathrm{BP}\right) / \mathrm{BP} \times 100
\end{aligned}
$$

The $\mathrm{F}_{1}$ hybrid performance, MPH and BPH was tested for significance by an ordinary $t$-test (Dreisigacker et al., 2005). Genetic and phenotypic correlations among the traits, and their standard errors, were estimated using multivariate REML implemented in the MIXED procedure of SAS (SAS Institute, 2003).

Table 1. Analysis of variance of nine traits of a half diallel cross among six spring wheat varieties differing in salt

\begin{tabular}{|c|c|c|c|c|c|c|c|c|c|}
\hline SOV & $\begin{array}{l}\text { Days to } \\
\text { heading }\end{array}$ & $\begin{array}{l}\text { Days to } \\
\text { Maturity }\end{array}$ & $\begin{array}{c}\text { Plant } \\
\text { Height }\end{array}$ & $\begin{array}{l}\text { Fertile tillers } \\
\text { plant }^{-1}\end{array}$ & $\begin{array}{l}\text { Spike } \\
\text { length }\end{array}$ & $\begin{array}{l}\text { Spikelets } \\
\text { spike }^{-1}\end{array}$ & $\begin{array}{l}\text { Grains } \\
\text { spike }^{-1}\end{array}$ & $\begin{array}{c}100 \text { grain } \\
\text { weight }\end{array}$ & $\begin{array}{l}\text { Yield } \\
\text { plant }^{-1}\end{array}$ \\
\hline Block & ns & ns & 7 & 5 & ns & ns & 5 & $\mathrm{~ns}$ & ns \\
\hline Genotype & $65 * *$ & $74 * *$ & $83 * *$ & $39 * *$ & $57 * *$ & $26^{*}$ & $58 * *$ & $75 * *$ & $74 * *$ \\
\hline Parents $(\mathrm{P})^{\mathrm{a}}$ & $55 * *$ & $68 * *$ & $72 * *$ & $81 * *$ & $75 * *$ & $73 * *$ & $12^{\mathrm{ns}}$ & $23 * *$ & $45 * *$ \\
\hline Crosses $(C)^{\mathrm{a}}$ & $45 * *$ & $32 * *$ & $28 * *$ & $19^{\mathrm{ns}}$ & $25^{*}$ & $27^{\mathrm{ns}}$ & $88 * *$ & $77 * *$ & $55 * *$ \\
\hline $\mathrm{P}$ vs. C & ns & ns & ns & ns & $* *$ & ns & ns & $* *$ & $* *$ \\
\hline Residual & 35 & 26 & 16 & 56 & 43 & 74 & 37 & 25 & 26 \\
\hline
\end{tabular}
tolerance

*** Significant at $\mathrm{P}<0.01$, and $\mathrm{P}<0.05$, respectively, on the basis of likelihood ratio test.

${ }^{\mathrm{ns}}$ not significant $(\mathrm{P} \geq 0.05),{ }^{\mathrm{a}}$ Proportions of the sum of parents and crosses. 
Table 2. Best linear unbiased predictors (BLUPs) of genotypes for nine traits in a half diallel cross among six spring wheat varieties differing in salt tolerance

\begin{tabular}{|c|c|c|c|c|c|c|c|c|c|}
\hline Genotypes & $\begin{array}{l}\text { Days to } \\
\text { heading }\end{array}$ & $\begin{array}{l}\text { Days to } \\
\text { maturity }\end{array}$ & $\begin{array}{l}\text { Plant } \\
\text { height }\end{array}$ & $\begin{array}{l}\text { Fertile } \\
\text { tillers } \\
\text { plant }^{-1}\end{array}$ & $\begin{array}{l}\text { Spike } \\
\text { length }\end{array}$ & $\begin{array}{l}\text { Spikelet } \\
\text { s spike }^{-1}\end{array}$ & $\begin{array}{l}\text { Grain } \\
\text { spike }^{-1}\end{array}$ & $\begin{array}{c}100 \\
\text { grain } \\
\text { weight }\end{array}$ & $\begin{array}{l}\text { Yield } \\
\text { plant }^{-1}\end{array}$ \\
\hline Frontana & 113.9 & 149.4 & 70.4 & 3.7 & 7.8 & 14.7 & 30.6 & 2.7 & 2.6 \\
\hline Local white & 116.5 & 154.8 & 84.5 & 5.5 & 9.2 & 16.3 & 28.1 & 2.2 & 4.9 \\
\hline Pavon & 108.3 & 145.6 & 55.1 & 3.5 & 9.4 & 16.1 & 35.5 & 2.7 & 4.2 \\
\hline Tobari 66 & 106.6 & 138.4 & 57.9 & 3.5 & 7.4 & 15.5 & 35.8 & 2.1 & 2.6 \\
\hline Pasban 90 & 108.0 & 134.2 & 51.7 & 4.6 & 9.3 & 16.2 & 32.6 & 2.3 & 4.7 \\
\hline Chakwal 97 & 106.3 & 136.9 & 57.6 & 3.0 & 7.8 & 14.6 & 30.3 & 2.0 & 1.9 \\
\hline $\begin{array}{l}\text { Frontana } \times \\
\text { Local white }\end{array}$ & 116.2 & 159.0 & 66.7 & 4.6 & 9.1 & 15.8 & 35.7 & 4.1 & 6.0 \\
\hline $\begin{array}{c}\text { Frontana } \times \\
\text { Pavon }\end{array}$ & 113.4 & 145.6 & 60.1 & 2.6 & 7.9 & 15.3 & 28.6 & 3.8 & 4.1 \\
\hline $\begin{array}{l}\text { Frontana } \times \\
\text { Tobari } 66\end{array}$ & 110.0 & 147.3 & 73.3 & 4.4 & 8.3 & 15.1 & 32.7 & 3.9 & 5.6 \\
\hline $\begin{array}{l}\text { Frontana } \times \\
\text { Pasban } 90\end{array}$ & 107.4 & 140.5 & 53.6 & 4.2 & 8.6 & 15.7 & 29.3 & 3.9 & 4.8 \\
\hline $\begin{array}{l}\text { Frontana } \times \\
\text { Chakwal } 97\end{array}$ & 111.7 & 147.0 & 60.7 & 3.5 & 9.2 & 15.9 & 33.8 & 3.8 & 4.9 \\
\hline $\begin{array}{c}\text { Local white } \times \\
\text { Pavon }\end{array}$ & 118.2 & 153.3 & 70.1 & 3.5 & 8.9 & 15.3 & 22.5 & 4.2 & 5.6 \\
\hline $\begin{array}{c}\text { Local white } \times \\
\text { Tobari } 66\end{array}$ & 106.6 & 146.7 & 77.9 & 4.2 & 10.1 & 17.5 & 46.7 & 4.0 & 8.9 \\
\hline $\begin{array}{c}\text { Local white } \times \\
\text { Pasban } 90\end{array}$ & 104.6 & 139.6 & 55.4 & 4.2 & 9.1 & 15.5 & 34.9 & 3.9 & 6.1 \\
\hline $\begin{array}{l}\text { Local white } \times \\
\text { Chakwal } 97\end{array}$ & 109.7 & 146.1 & 66.1 & 3.5 & 8.2 & 15.0 & 27.5 & 3.8 & 6.2 \\
\hline $\begin{array}{l}\text { Pavon } \times \\
\text { Tobari } 66\end{array}$ & 107.2 & 141.1 & 57.3 & 3.3 & 9.2 & 15.9 & 33.7 & 3.6 & 4.6 \\
\hline $\begin{array}{c}\text { Pavon } \times \\
\text { Pasban } 90\end{array}$ & 106.3 & 138.1 & 51.4 & 3.0 & 9.8 & 16.1 & 35.0 & 3.8 & 5.3 \\
\hline $\begin{array}{c}\text { Pavon } \times \\
\text { Chakwal } 97\end{array}$ & 109.4 & 142.9 & 58.2 & 3.3 & 9.4 & 16.7 & 22.0 & 3.5 & 5.1 \\
\hline $\begin{array}{l}\text { Tobari 66× } \\
\text { Pasban } 90\end{array}$ & 110.3 & 142.0 & 55.4 & 4.4 & 8.8 & 16.5 & 25.1 & 1.9 & 1.9 \\
\hline $\begin{array}{l}\text { Tobari } 66 \times \\
\text { Chakwal } 97\end{array}$ & 106.6 & 139.6 & 60.4 & 3.7 & 9.6 & 17.1 & 43.4 & 3.2 & 7.0 \\
\hline $\begin{array}{l}\text { Pasban } 90 \times \\
\text { Chakwal } 97\end{array}$ & 110.3 & 146.7 & 54.8 & 3.5 & 9.9 & 16.4 & 33.1 & 3.9 & 5.8 \\
\hline $\mathrm{SE}^{*}$ & 2.3 & 3.0 & 3.3 & 0.7 & 0.5 & 1.0 & 3.9 & 0.4 & 0.8 \\
\hline
\end{tabular}

* Standard error of the difference between BLUPs. 


\section{Results}

Genotypes $\left(\mathrm{F}_{1}\right.$ and parents) differed significantly $(\mathrm{P}<0.05)$ for all traits studied. Variance due to genotypes was more than $50 \%$ for all the studied traits except fertile tillers plant ${ }^{-1}$ and spikelets spike ${ }^{-1}$ (Table 1 ). The effects of parents were significant $(\mathrm{P}<0.05)$ for all traits but grain spike ${ }^{-1}$. Genotypic variance for crosses were also significant $(\mathrm{P}<0.05)$ for all traits but fertile tillers plant ${ }^{-1}$ and spikelets spike ${ }^{-1}($ Table 1$)$.

Local white was the latest of the six cultivars followed by Frontana, Pavon, Pasban 90, Chakwal 97 and Tobari 66 in descending order of days to heading and maturity. The $F_{1}$ crosses involving Frontana and Local white also matured later than other crosses (Table 2). Local white was the tallest parent followed by Frontana. Pasban 90 and the crosses involving it had the shortest plants. The $F_{1}$ crosses involving Local white and Frontana were also taller than the crosses not involving these parents. Local white and Pasban 90, and the crosses involving these produced the maximum fertile tillers plant ${ }^{-1}$. The longest spikes were produced by Pavon, Local white and Pasban 90 . The $F_{1}$ crosses involving Pavon, Local white and Pasban 90 also produced the longest spikes (Table 2). Local white and its crosses had the maximum spikelets spike ${ }^{-1}$. Tobari 66 and two of its $F_{1}$ crosses had maximum grains spike ${ }^{-1}$. Pavon and Frontana, and the crosses involving these had the highest 100 grain weight. The $F_{1}$ crosses of these parents also produced the highest grain spike ${ }^{-1}$. Local white and its crosses had the highest yield plant ${ }^{-1}$ (Table 2). Local white, Pavon and Pasban 90, and the crosses involving one of these performed better than the other three parents under $200 \mathrm{mM} \mathrm{NaCl}$ stress.

Additive genetic effects were significant $(\mathrm{P}<0.01)$ for days to heading and maturity, plant height and fertile tillers plant $^{-1}$ (Table 3). Additive genetic effects were $>50 \%$ of the total phenotypic variation in days to maturity and plant height. Dominance effects were significant $(\mathrm{P}<0.05)$ for all traits studied. Dominance effects were $>75 \%$ of the total variability in 100 grain weight and yield plant ${ }^{-1}$ (Table 3 ).

Narrow sense $\left(\mathrm{h}^{2} \mathrm{~N}\right)$ heritability estimates were significant $(\mathrm{P}<0.01)$ for days to heading and maturity, plant height and fertile tillers plant ${ }^{-1}$ (Table 3 ). Narrow sense $\left(\mathrm{h}^{2}{ }_{\mathrm{N}}\right)$ heritability estimates ranged from 0 to $51 \%$. Broad sense $\left(\mathrm{h}^{2}{ }_{\mathrm{B}}\right)$ heritability estimates were significant $(\mathrm{P}<0.01)$ for all the traits studied and ranged from 25 to $84 \%$. Broad sense heritability estimates were relatively low for spikelets spike ${ }^{-1}(27 \%)$ and fertile tillers plant ${ }^{-1}(41 \%)$, but higher for the rest of the traits studied (Table 3).

Table 3. Percent proportions of variance components to total phenotypic variance for nine agronomic traits in $F_{1}$ of a half diallel cross among six spring wheat varieties differing in salt tolerance

\begin{tabular}{llllllllll}
\hline & $\begin{array}{l}\text { Days to } \\
\text { heading }\end{array}$ & $\begin{array}{l}\text { Days to } \\
\text { Maturity }\end{array}$ & $\begin{array}{l}\text { Plant } \\
\text { Height }\end{array}$ & $\begin{array}{l}\text { Fertile } \\
\text { tillers } \\
\text { plant }\end{array}$ & $\begin{array}{l}\text { Spike } \\
\text { length }\end{array}$ & $\begin{array}{l}\text { Spikelets } \\
\text { spike }\end{array}$ & $\begin{array}{l}\text { Grains } \\
\text { spike }\end{array}$ & $\begin{array}{l}100 \\
\text { grain } \\
\text { weight }\end{array}$ & $\begin{array}{l}\text { Yield } \\
\text { plant }^{-1}\end{array}$ \\
\hline $\mathrm{V}_{\mathrm{A}} / \mathrm{V}_{\mathrm{p}}$ & $27^{* *}$ & $51^{* *}$ & $64^{* *}$ & $33^{* *}$ & $\mathrm{~ns}$ & $\mathrm{~ns}$ & $\mathrm{~ns}$ & $\mathrm{~ns}$ & $\mathrm{~ns}$ \\
$\mathrm{~V}_{\mathrm{D}} / \mathrm{V}_{\mathrm{P}}$ & $37^{* *}$ & $23^{* *}$ & $20^{* *}$ & $8^{*}$ & $53^{* *}$ & $25^{* *}$ & $64^{* *}$ & $77^{* *}$ & $76^{* *}$ \\
$\mathrm{~V}_{\mathrm{E}} / \mathrm{V}_{\mathrm{P}}$ & $36^{* *}$ & $26^{* *}$ & $16^{* *}$ & $59^{* *}$ & $43^{* *}$ & $75^{* *}$ & $36^{* *}$ & $23^{* *}$ & $24^{* *}$ \\
$\mathrm{~h}^{2}{ }_{\mathrm{N}}$ & $27^{* *}$ & $51^{* *}$ & $64^{* *}$ & $33^{* *}$ & $\mathrm{~ns}$ & $\mathrm{~ns}$ & $\mathrm{~ns}$ & $\mathrm{~ns}$ & $\mathrm{~ns}$ \\
$\mathrm{~h}^{2}{ }_{\mathrm{B}}$ & $64^{* *}$ & $74^{* *}$ & $84^{* *}$ & $41^{* *}$ & $57^{* *}$ & $25^{* *}$ & $64^{* *}$ & $77^{* *}$ & $76^{* *}$ \\
\hline
\end{tabular}

**, * Significantly different at $\mathrm{P}<0.01$ and $\mathrm{P}<0.05$, respectively, from zero; ${ }^{\text {ns }}$ Non-significant $(\mathrm{P} \geq 0.05)$

$\mathrm{h}^{2}{ }_{\mathrm{N}}$ and $\mathrm{h}_{\mathrm{B}}^{2}$ are heritabilities in narrow and broad-sense, respectively, $\mathrm{V}=$ Variance, $\mathrm{P}=$ Phenotypic, $\mathrm{A}=$ Additive, $\mathrm{D}=$ Dominance, $\mathrm{E}=$ Residual .

Analysis of the relative importance of general combining ability (GCA) and specific combining ability (SCA) effects provides an indication of the type of gene action involved in the expression of traits. Frontana and Local white had significant $(\mathrm{P}<0.01)$ positive GCA $(2.12$ and 2.33 , respectively) for days to heading. High positive SCAs for days to heading were recorded for the crosses 'Local white $\times$ Pavon' (7.10) and 'Tobari $66 \times$ Pasban 90' (4.17). The highest positive GCA effects for days to maturity were observed for Local white (5.56) and Frontana (3.46). Significant $(\mathrm{P}<0.05)$ SCAs were found for days to maturity for the crosses 'Pasban $90 \times$ Chakwal 97' (8.31) and 'Frontana $\times$ Local white' $(7.51)$. Significant $(\mathrm{P}<0.01)$ positive GCA effects were observed for Local white $(9.20)$ and Frontana (2.84). Significant $(\mathrm{P}<0.05)$ positive SCAs for plant height were observed for the crosses 'Frontana $\times$ Tobari 66' (8.62) and 'Local white $\times$ Tobari 66' (7.92). 
Local white (0.74), Pavon (-0.66) and Chakwal $97(0.50)$ exhibited significant $(\mathrm{P}<0.01)$ GCA for fertile tillers plant $^{-1}$. Significant $(\mathrm{P}<0.05)$ positive SCAs were found for spike length for the crosses 'Frontana $\times$ Chakwal 97' (0.96), 'Local white $\times$ Tobari 66' (1.53), 'Pavon $\times$ Pasban 90' (0.55), 'Tobari $66 \times$ Chakwal 97' (1.12) and 'Pasban $90 \times$ Chakwal 97' $(0.98)$. Significant $(\mathrm{P}<0.05)$ positive SCAs for spikelets spike ${ }^{-1}$ were observed for the crosses 'Local white $\times$ Tobari 66' (2.10), 'Pavon $\times$ Chakwal 97' (1.35) and 'Pasban $90 \times$ Chakwal 97' (0.73). Significant $(\mathrm{P}<0.01)$ positive SCAs were found for grains spike ${ }^{-1}$ for the crosses 'Local white $\times$ Tobari 66 ' (15.07) and 'Tobari $66 \times$ Chakwal 97' (11.26). Significant $(\mathrm{P}<0.01)$ positive SCAs were observed for 100 grain weight for the crosses 'Frontana $\times$ Tobari 66' $(0.83)$, 'Local white $\times$ Pavon' $(0.75)$, 'Local white $\times$ Tobari 66' (0.99), 'Local white $\times$ Pasban' $(0.78)$, and 'Pasban $90 \times$ Chakwal 97' $(0.96)$. Significant $(\mathrm{P}<0.05)$ positive SCAs for yield plant ${ }^{-1}$ were detected for crosses 'Local white $\times$ Tobari 66' (3.92), 'Pavon $\times$ Pasban 90' $(0.80)$, 'Tobari $66 \times$ Chakwal 97' (2.88) and 'Pasban $90 \times$ Chakwal 97' (1.42).

Table 4. Mid parent heterosis values for some quantitative wheat traits in 15 hybrids

\begin{tabular}{|c|c|c|c|c|c|c|c|c|c|}
\hline Cross & DH & $\mathrm{DM}$ & $\mathrm{PH}$ & FTP & SL & SS & GS & TGW & YPP \\
\hline Frontana $\times$ Local white & 0.7 & 5.0 & -14.7 & -14.7 & 8.9 & 3.3 & 26.9 & 74.0 & 67.7 \\
\hline Frontana $\times$ Pavon & 2.2 & -2.9 & -4.8 & -4.8 & -10.8 & -1.1 & -16.1 & 46.1 & 22.7 \\
\hline Frontana $\times$ Tobari 66 & -0.5 & 2.6 & 14.7 & 14.7 & 11.0 & 0.4 & -1.8 & 74.5 & 144.5 \\
\hline Frontana $\times$ Pasban 90 & -4.0 & -1.1 & -13.1 & -13.1 & 0.0 & 3.0 & -8.8 & 68.5 & 34.4 \\
\hline Frontana $\times$ Chakwal 97 & 1.4 & 3.0 & -5.2 & -5.2 & 23.2 & 18.5 & 13.7 & 75.5 & 148.6 \\
\hline Local white $\times$ Pavon & 5.9 & 2.2 & 0.2 & 0.2 & -5.9 & -11.1 & -35.6 & 82.2 & 26.0 \\
\hline Local white $\times$ Tobari 66 & -5.4 & 0.0 & 9.7 & 9.7 & 27.2 & 18.8 & 56.1 & 103.1 & 158.2 \\
\hline Local white $\times$ Pasban 90 & -8.3 & -3.8 & -19.7 & -19.7 & -1.5 & -9.0 & 18.4 & 93.0 & 30.8 \\
\hline Local white $\times$ Chakwal 97 & -2.1 & 0.2 & -7.2 & -7.2 & -4.0 & -6.6 & -7.0 & 96.8 & 94.5 \\
\hline Pavon $\times$ Tobari 66 & -0.3 & -0.9 & 0.9 & 0.9 & 11.4 & 1.5 & -7.8 & 55.2 & 39.9 \\
\hline Pavon $\times$ Pasban 90 & -2.2 & -1.6 & -4.4 & -4.4 & 5.6 & -0.3 & 3.2 & 60.9 & 21.6 \\
\hline Pavon $\times$ Chakwal 97 & 2.2 & 1.2 & 3.6 & 3.6 & 11.8 & 17.2 & -39.8 & 56.3 & 77.2 \\
\hline Tobari $66 \times$ Pasban 90 & 3.1 & 4.6 & 0.9 & 0.9 & 5.7 & 8.2 & -31.9 & -14.8 & -56.7 \\
\hline Tobari $66 \times$ Chakwal 97 & 0.0 & 1.5 & 4.9 & 4.9 & 33.6 & 27.2 & 37.8 & 64.0 & 270.6 \\
\hline Pasban $90 \times$ Chakwal 97 & 3.1 & 9.3 & 0.6 & 0.6 & 19.4 & 13.0 & 6.2 & 96.8 & 80.0 \\
\hline
\end{tabular}

$\mathrm{DH}=$ Days to heading; $\mathrm{DM}=$ Days to maturity; $\mathrm{PH}=$ Plant height; $\mathrm{FTP}=$ Fertile tillers per plant; $\mathrm{SL}=$ Spike length;

$\mathrm{SS}=$ Spikelets per spike; GS=Grains per spike; TGW=Thousand grain weight; YPP=Yield per plant.

Mid-parent heterosis (MPH) estimates for days to heading, days to maturity, plant height and fertile tillers plant ${ }^{-1}$ were less than 15\% (Table 4). This indicated that improvement in these traits through hybridization is difficult. The cross 'Tobari $66 \times$ Chakwal 97' had highest (33.6\%) MPH for spike length. This cross also had the maximum (27.1\%) MPH for spikelets spike ${ }^{-1}, 37.8 \%$ for grains spike $e^{-1}, 64 \%$ for 100 grain weight and $270.6 \%$ yield plant $^{-1}$. Highest (56\%) MPH for grains spike ${ }^{-1}$ was recorded for cross 'Local white $\times$ Tobari 66 '. This cross also had high MPH for 100 grain weight (103\%) and yield plant ${ }^{-1}(158 \%)$. Fourteen crosses had $>50 \%$ MPH for 100 grain weight. This indicated that there is a great potential in the cultivars to improve 100 grain weight which is an important yield contributing trait. Eight crosses showed $>50 \% \mathrm{MPH}$ for yield plant ${ }^{-1}$. Four crosses including 'Frontana $\times$ Tobari 66' (141\%), 'Frontana $\times$ Chakwal 97' (107\%), 'Local white $\times$ Tobari 66' $(89 \%)$ and Tobari $66 \times$ Chakwal $97(213)$ showed $>50 \%$ BPH for yield plant ${ }^{-1}$. The highest heterosis $(271 \%)$ for yield was recorded for cross 'Tobari $66 \times$ Chakwal 97'. High heterosis estimates for yield suggested that breeding for high yield under salt stress is possible if parents with better combining ability are crossed.

Generally genotypic correlation coefficients were higher than phenotypic correlation coefficients (Table 5). All the studied traits were positively correlated with yield plant $^{-1}$ except days to heading. Similar findings were also reported by previous workers (Ali, 2001; Yagdi, 2009). 
Table 5. Phenotypic (p) and genotypic (g) correlation coefficients among some quantitative traits in wheat

\begin{tabular}{|c|c|c|c|c|c|c|c|c|}
\hline & $\begin{array}{l}\text { Days to } \\
\text { Maturity }\end{array}$ & $\begin{array}{l}\text { Plant } \\
\text { Height }\end{array}$ & $\begin{array}{l}\text { Fertile tillers } \\
\text { plant }^{-1}\end{array}$ & $\begin{array}{l}\text { Spike } \\
\text { length }\end{array}$ & $\begin{array}{l}\text { Spikelets } \\
\text { spike }^{-1}\end{array}$ & $\begin{array}{l}\text { Grains } \\
\text { spike }^{-1}\end{array}$ & $\begin{array}{l}100 \text { grain } \\
\text { weight }\end{array}$ & $\begin{array}{l}\text { Yield } \\
\text { plant }^{-1}\end{array}$ \\
\hline \multirow[t]{2}{*}{ Days to heading } & p $0.80^{* *}$ & p $0.47 * *$ & p $0.25^{*}$ & p- 0.12 & $\mathrm{p}-0.16$ & $\mathrm{p}-0.31^{* *}$ & $\mathrm{p} 0.07$ & $\mathrm{p}-0.04$ \\
\hline & g $0.89 * *$ & $\operatorname{g~} 0.63 * *$ & g 0.24 & $\mathrm{~g}-0.14$ & $\mathrm{~g}-0.29$ & $\mathrm{~g}-9.57 * *$ & g 0.11 & g -0.04 \\
\hline \multirow[t]{2}{*}{ Days to Maturity } & & p $0.65^{* *}$ & p $0.23 * *$ & $\mathrm{p} 0.05$ & $\mathrm{p} 0.00$ & $\mathrm{p}-0.06$ & p $0.28 * *$ & p $0.23^{* *}$ \\
\hline & & $\operatorname{g~} 0.76^{* *}$ & g $0.43^{* *}$ & g 0.07 & g 0.16 & $\mathrm{~g}-0.20$ & g $0.32 * *$ & g $0.26^{* *}$ \\
\hline \multirow[t]{2}{*}{ Plant Height } & & & p $0.31^{* *}$ & $\mathrm{p}-0.01$ & p 0.03 & p 0.08 & p 0.08 & p $0.28 * *$ \\
\hline & & & $\mathrm{g} 0.62 * *$ & $\mathrm{~g}-0.07$ & $\mathrm{~g}-0.03$ & g 0.02 & g 0.07 & g $0.34 * *$ \\
\hline Fertile tillers & & & & p 0.25 & $\mathrm{p} 0.21$ & p 0.12 & $\mathrm{p}-0.14$ & p $0.20^{*}$ \\
\hline plant $^{-1}$ & & & & g 0.19 & g 0.32 & g 0.03 & $\mathrm{~g}-0.26$ & g 0.17 \\
\hline \multirow[t]{2}{*}{ Spike length } & & & & & p $0.73^{* *}$ & p $0.39 *$ & p $0.21 * *$ & p $0.52 * *$ \\
\hline & & & & & g $0.93 *$ & g 0.34 & g $0.40 * *$ & g $0.74 * *$ \\
\hline \multirow[t]{2}{*}{ Spikelets spike ${ }^{-1}$} & & & & & & p $0.42 * *$ & $\mathrm{p}-0.03$ & p $0.37 * *$ \\
\hline & & & & & & g 0.43 & g 0.10 & g $0.64 *$ \\
\hline \multirow[t]{2}{*}{ Grains spike $^{-1}$} & & & & & & & p 0.07 & p $0.40^{* *}$ \\
\hline & & & & & & & g 0.14 & g $0.49^{* *}$ \\
\hline \multirow[t]{2}{*}{100 grain weight } & & & & & & & & p $0.61 * *$ \\
\hline & & & & & & & & g $0.65^{* *}$ \\
\hline
\end{tabular}

**, * Significantly different at $\mathrm{P}<0.01$ and $\mathrm{P}<0.05$, respectively.

\section{Discussion}

The present study revealed that additive genetic effects are important in the inheritance of days to maturity and heading, plant height and fertile tiller plant ${ }^{-1}$ under $200 \mathrm{mM} \mathrm{NaCl}$ stress. This suggested that early selection could be useful to bring desirable changes in these characters under $\mathrm{NaCl}$ stress. The contribution of additive genetic effects in the inheritance of days to maturity was also reported by Iqbal et al. (2007). Estimates of broad sense heritability for most of the yield components were within the requisite range for the improvement of salinity tolerance in wheat. The high heritability estimates for a number of variables indicated that significant advances in salinity tolerance in wheat may be possible through selection. High SCA estimates indicated dominance gene effects and high GCA suggested major role of additive gene effects. Non significant GCA and SCA values indicate epistatic gene effects (Fehr, 1993). However, in wheat, additive $\times$ additive interaction component is fixable in later generations. Number of fertile tillers directly contributes to crop yield. 'Local white' proved to be the best general combiner to increase fertile tillers plant ${ }^{-1}$. Negative GCA effects of two parents 'Tobari 66' and 'Pasban 90' indicated that these parents could be used to incorporate early maturity in wheat.

Early heading is desirable because it provides sufficient time for grain formation and filling. Seven crosses showed negative heterosis for days to heading. Genotypes with early maturing habits are generally required to avoid stress conditions. Therefore, negative heterosis for days to heading and maturity is useful. Five $F_{1}$ crosses had negative MPH and could be used to incorporate earliness. Workers (Dreisigacker, 2005; Sadeque, 1991; Inamullah, 2006) also reported negative heterosis for days to heading and maturity and reported the importance of heterotic studies for incorporating earliness in wheat. Tall plants expected to lodge quite often. They require more energy to translocate solutes to the grain and have lower grain weight. Short stature wheat is therefore preferred and negative heterosis is desirable. Seven crosses showed negative heterosis for plant height. Dreisigacker (2005) and Sadeque (1991) had reported negative as well as positive heterosis for plant height.

Spike length is directly associated with number of grains. Positive MPH has been reported for spike length (Thakur, 1991), while negative MPH was reported for spike length in wheat genotypes (Sadeque, 1991). Most of the crosses had positive MPH for grains spike ${ }^{-1}, 100$ grain weight and yield plant $^{-1}$. This showed the effectiveness of heterosis for increased grain yield under salinity stress. Similar findings were reported by Afia (2000). Above $50 \%$ MPH of eight crosses and BPH for four crosses suggested that hybrids could yield better under salt stress conditions. Our results showed high heterosis for yield plant ${ }^{-1}$ which was particularly observed under salinity stress. Earlier, 
Walton (1971) reported 92\% MPH for grain yield. Our results showed that heterosis could improve grain yield and provide sufficient chance to select the desired combinations under salinity stress.

Positive correlation of days to heading and maturity with plant height and fertile tillers plant ${ }^{-1}$ suggested that delayed crop maturity leads to better crop growth. Negative correlation between days to heading and yield plant ${ }^{-1}$ suggested that early maturity helps plant to avoid stress and increases crop yield under salinity stress. All the yield attributing traits displayed positive correlation at both genotypic and phenotypic level with yield plant ${ }^{-1}$, indicating that all these traits contributed towards yield under $\mathrm{NaCl}$ stress.

Three parents, 'Local white', 'Pavon' and 'Pasban 90', and their $F_{1}$ crosses performed better on the basis of yield and yield components under $\mathrm{NaCl}$ stress. These parents can, therefore, serve as donor parents for developing salt tolerant wheat varieties. Significance of additive effects for days to heading, days to maturity, plant height and fertile tillers plant ${ }^{-1}$ suggested that selection in early breeding generations could be effective to bring positive changes in these traits under salt stress. High dominance effects for yield and yield contributing traits indicated that selection for yield and yield components under salt stress could be effective in later generations. Above $50 \% \mathrm{MPH}$ of eight crosses and BPH for four crosses suggested that hybrids could yield better under salt stress conditions. Narrow sense $\left(h^{2}{ }_{N}\right)$ heritability estimates ranged from $0-51 \%$, whereas broad sense $\left(h^{2}{ }_{B}\right)$ heritability estimates ranged from $25-84 \%$ for the studied traits. On the basis of yield and yield components, crosses 'Local white $\times$ Tobari 66', 'Tobari $66 \times$ Chakwal 97', 'Frontana $\times$ Local white', 'Local white $\times$ Pasban 90', 'Pavon $\times$ Pasban 90' might be better choice to get high yield under $\mathrm{NaCl}$ stress conditions.

\section{Acknowledgements}

This study was financially supported by Research for Agricultural Development Program (RADP) of Pakistan Agricultural Research Council. The authors are grateful Plant Genetic Resources Program, National Agricultural Research Centre for providing seeds.

\section{References}

Afia, S. A., Mohammad, N., \& Saleem, M. M. (2000). Statistical genetic parameters, heritability and graphical analysis in $8 \times 8$ wheat diallel cross under saline conditions. Annals of Agricultural Science (Cairo), 45, 257-280.

Ali, Z. (2004). Genetic basis of salt tolerance in wheat. Ph. D. Dissertation. University of Agriculture Faisalabad Pakistan.

Ashraf, M. (1994). Genetic variation for salinity tolerance in spring wheat. Hereditas, 120, 99-104.

Chatrath, R., Mishra, B., Ferrara, G. O., Singh, S. K., \& Joshi, A. K. (2007). Challenges to wheat production in South Asia. Euphytica, 157, 447-456. http://dx.doi.org/10.1007/s10681-007-9515-2

Chen, G., \& Zhu, J. (2003). QGA Station 1.0. Software for the classical quantitative genetics. Institute of Bioinformatics, Zhejiang University, China.

Dreisigacker, S., Melchinger, A. E., Zhang, P., Ammar, K., Flachnecher, C., Hoisington, D., \& Warburton, M. L. (2005). Hybrid performance and heterosis in spring bread wheat, and their relations to SSR-based genetic distances and coefficients of parentage. Euphytica, 144, 51-59. http://dx.doi.org/10.1007/s10681-005-4053-2

Fehr, W. R. (1993). Principles of Cultivar Development: Development of Hybrid Cultivars. New York: Macmillan Publishing Company.

Inamullah, A., Mohammad, H., Siraj-ud-Din, F., Hassan, G., \& Gul, R. (2006). Evaluation of the heterotic and heterobeltiotic potential of wheat genotypes for improved yield. Pak. J. Bot., 38, 1159-1167.

Iqbal, M., Navabi, A., Salmon, D. F., Yang, R., Murdock, B. M., Moore, S. S., \& Spanner, D. (2007). Genetic analysis of flowering and maturity time in high latitude spring wheat. Euphytica, 154, 207-218. http://dx.doi.org/10.1007/s10681-006-9289-y

Kumar, A., Mishra V. K., Vyas R. P., \& Singh V. (2011). Heterosis and combining ability analysis in bread wheat (Triticum aestivum L.). J. Plant Breed. \& Crop Sci., 3(10), 209-217.

Munns, R. (2005). Genes and salt tolerance: bringing them together. New Phytologist, 167, 645-663.

Qureshi, R. H., Rashid, A., \& Ahmed, N. (1990). A procedure for quick screening of wheat cultivars for salt tolerance. In B. C. Loughman (Ed.), Genetic Aspects of Plant Mineral Nutrition (pp. 315-324). Amsterdam: Kluwer Academic Publishers. 
Rao, C. R. (1971). Estimation of variance and covariance components-MINQUE theory. J. Multivariate Analysis, $1,257-275$.

Sadeque, Z., Bhowmik, A., \& Ali, M. S. (1991). Estimates of heterosis in wheat (Triticum aestivum L.). Annals of Bangladesh Agriculture, 1, 75-79.

SAS Institute. (2003). Release 9.1. SAS Institute, Inc. Cary NC USA.

Singh, S., \& Singh, M. (2000). Genotypic basis of response to salinity stress in some crosses of spring wheat Triticum aestivum L. Euphytica, 115, 209-214.

Stuber, C. W. (1994) Heterosis in plant breeding. Plant Breeding, 12, 227-251.

Thakur, K. S., Dawa, T., Plaha, P., \& Sethi, G. S. (1991). Heterosis in spring x winter wheat crosses. SABRAO J. Breed. Genet., 23, 15-19.

Walton, P. D. (1971). Heterosis in spring wheat. Crop Science, 11, 422-424.

Yagdi, K. (2009). Path coefficient analysis of some yield components in durum wheat (Triticum durum DESF). Pak. J. Bot., 41, 745-751.

Yanchuk, A. D. (1996). General and specific combining ability from disconnected partial diallels of coastal Douglas-fir. Silvae Genetica, 45, 37-45.

Zhu, J. (2003). Diallel analysis for an additive-dominance epistasis model with genotype-by-environment interaction effects. In M. S. Kang (Ed.), Handbook of Formulas and Software for Plant Geneticists and Breeders. Haworth press New York USA.

Zhu, J., \& Weir, B. S. (1996). Mixed model approaches for diallel analysis on a bio-model. Genetics Research (Camb), 68, 233-240. 